\title{
The search for verisimilitudinous knowledge
}

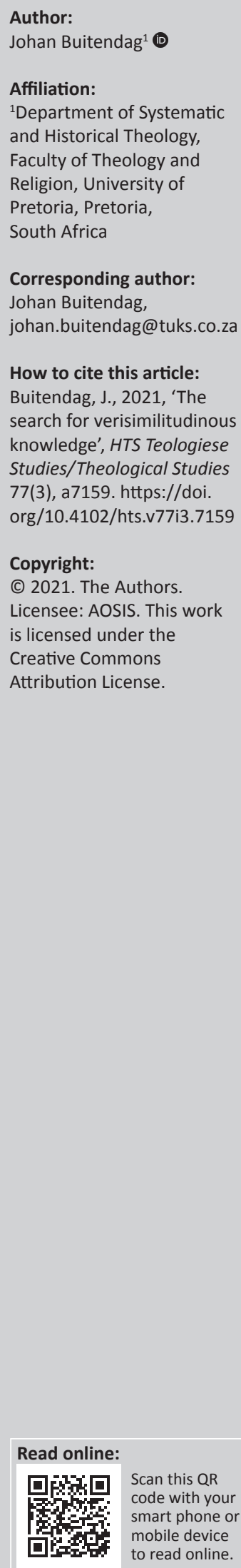

The expression of the title is borrowed from John Polkinghorne (1998:20, 2000:33, 35-36), a prominent doyen of the science and religion dialogue of the previous century and Templeton laureate who passed away on 19 March 2021 at the age of 90 years ${ }^{1}$. Alister McGrath (2019) describes this aptly:

We may live in a world that is an ontological unity, but this world is investigated and represented based on an epistemological pluralism, offering us a bricolage of unintegrated insights and perceptions arising from different disciplinary or cultural perspectives on our world, or scientific engagement with its different levels. It is not difficult to develop theoretical nets which help us visualise the interconnectedness of these perceptions, or understand how they arise from the exercise of their specific disciplinary rationalities. What remains stubbornly elusive is their failure to provide means of calibrating their respective reliabilities, or to offer a theoretical framework that allows the settling of boundary disputes, or precise coordination of their interactions. (pp. 222-223)

This collection of essays on 'Theology and Nature' is now in its second of a three-year cycle. Last year I leaned on Darwin in my editorial and which was titled 'Grandeur in this view of life' and complemented it by Jan Smuts' holistic understanding of reality: matter - life - mind.

As mentioned elsewhere, I consider theology as 'a scholarly endeavour of believers in the public sphere to inquire into a multi-dimensional reality in a manner that matters' (Buitendag 2014:6). This leads to the intellectual pursuit of three crucial inquiries: 'the exploration of the nature of existence (metaphysics), the nature of knowledge (epistemology) and the nature of values (axiology)' (Grenz 2005:2).

In a recently republished book of A.N. Whitehead ([1925] 2021:viii) he states that the various human interests, which suggest cosmologies, and also are influenced by them, are science, aesthetics, ethics and religion:

Philosophy, in one of its functions, is the critic of cosmologies. Its function is to harmonise, refashion, and justify divergent intuitions as to the nature of things. It has to insist on the scrutiny of the ultimate ideas, and on the retention of the whole of the evidence in shaping our cosmological scheme. Its business is to render explicit, and - so far as may be - efficient, a process which otherwise is unconsciously performed without rational tests. (p. viii)

Subsequently, it is vital to discern an indistinctive faith that there is order in nature. Friedrich Wilhelm Heinrich Alexander von Humboldt conceived the web of life, that is, the concept of an integrated nature as we know it today. Von Humboldt brings this very appropriately in the following words in his multivolume Cosmos: A Sketch of the Physical Description of the Universe:

When the human mind first attempts to subject to its control the world of physical phenomena, and strives by meditative contemplation to penetrate the rich luxuriance of living nature, and the mingled web of free and restricted natural forces, man feels himself raised to a height from whence, as he embraces the vast horizon, individual things blend in varied groups, and appear as if shrouded in a vapory vail. These figurative expressions are used to illustrate the point of view from whence we would consider the universe both in its celestial and terrestrial sphere. (Von Humboldt 1858:104)

Last year we published 13 scholarly articles regarding theology and nature, and this year, coincidentally again, $13^{2}$. These 26 articles engage with the given backdrop from different angles, spheres of life and even faith vantage points. Indeed, offering an authenticity of knowledge. To my knowledge, they are the most extensive collection of journal articles addressing the given challenge.

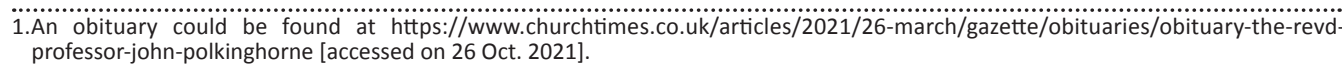

2.Please see: https://hts.org.za/index.php/hts/browseSearch/sections/view?sectionld=160 [accessed on 26 Oct. 2021] for the respective authors and their topics. 
We are grateful to the editor of the HTS Theological Studies for allowing space for this collection and the Faculty of Theology and Religion of the University of Pretoria for partially subsidising some articles.

I would like to extend my sincerest gratitude to all my co-researchers and contributors to this collection! You have endowed this selection with an international profile of excellence.

In Paragraph 74 of his encyclical letter of 1998, Fides et Ratio, Pope John Paul II expressed his appreciation and even admiration for the scientific achievements of our time. The Pope (1998) said this with a crucial caveat:

$[W]$ ithout ever abandoning the sapiential horizon within which scientific and technological achievements are wedded to the philosophical and ethical values, which are the distinctive and indelible mark of the human person. (p. 106)

The stratification of the quest for truth prevails and so the demise of an ontotheology.

This approach lays the table to revisit our terminology. Since Kant and Heidegger, it has become clear that a theo-ontology is unacceptable. Kant believed that the existence of God could be known without recourse to revelation, very much like the ontological arguments of Anselm (1033-1109) and Descartes (1596-1650). Faith is relegated to practical reason and excluded from pure reason. In his turn, Martin Heidegger (1889-1976) criticises the Western metaphysical tradition of being onto-theo-logic and subsequently fails to explain how God enters into philosophy.
This results now in the question if we should not replace the concept of eco-theology with the term theo-ecology? This would advance our dialogue with the sciences as the common denominator is now nature (creation) contemplated from an a priori: The question is not what the implication of ecology is for theology, but rather the inverse, what is the implication of the Named God for ecology ${ }^{3}$

\section{Acknowledgements}

I would like to extend my sincerest gratitude to all my co-researchers and contributors to this collection.

\section{References}

Buitendag, J., 2014, 'Between the Scylla and the Charybdis: Theological education in the 21st century in Africa', HTS Teologiese Studies/Theological Studies 70(1), a2855. https://doi.org/10.4102/hts.v70i1.2855

Grenz, S.J., 2005, The named God and the question of being: A trinitarian theoontology, Westminster John Knox Press, Louisville, KY.

McGrath, A.E., 2019, The territories of human reason (Ian Ramsey Centre Studies in Science and Religion), Oxford University Press, Oxford.

Polkinghorne, J., 1998, Science \& theology, Fortress Press, Minneapolis, MN.

Polkinghorne, J., 2000, Faith, science and understanding, Yale University Press, London.

Pope J.P. II, 1989, Encyclical letter: Fides et Ratio, viewed 14 August 2021, from https:// www.vatican.va/content/john-paul-ii/en/encyclicals/documents/hf_jp-ii_enc_ 14091998_fides-et-ratio.pdf.

Von Humboldt, A., 1858, Cosmos - A sketch of the physical description of the universe, vol. 1, transl. E. C. Otto and eBook prepared by Amy Zelmer, Harper \& Brothers, New York, NY.

Whitehead, A.N., [1925] 2021, Science and the modern world, Open Road Media, New York, NY.

3.In this topic, I intend to explore in a forthcoming publication of Verbum et Ecclesid and perhaps next year in the final cycle of this collection, 'Theology and Nature'. 